\title{
An inter-organisational perspective on challenges in one-stop government
}

\author{
Karin Axelsson and Ulf Melin
}

\section{Linköping University Post Print}

\section{Tweet}

N.B.: When citing this work, cite the original article.

Original Publication:

Karin Axelsson and Ulf Melin, An inter-organisational perspective on challenges in one-stop government, 2008, International Journal of Electronic Governance, (1), 3, 296-314. http://dx.doi.org/10.1504/IJEG.2008.020451

Copyright: Inderscience

http://www.inderscience.com/

Postprint available at: Linköping University Electronic Press

http://urn.kb.se/resolve?urn=urn:nbn:se:liu:diva-43888 


\title{
AN INTER-ORGANIZATIONAL PERSPECTIVE ON CHALLENGES IN ONE-STOP GOVERNMENT
}

\author{
Axelsson, Karin, Linköping University, Department of Management and Engineering, Sweden, \\ karin.axelsson@liu.se \\ Melin, Ulf, Linköping University, Department of Management and Engineering, Sweden, \\ ulf.melin@liu.se
}

\begin{abstract}
Fragmentation and isolated development are main problems that hinder successful e-government in many situations. This paper therefore has an explicit inter-organizational perspective on challenges in one-stop government. In order to capture the inter-organizational perspective we present a conceptual framework, derived from the industrial/business network approach, that characterizes an interorganizational relationship and its dimensions. The conceptual framework is used for analyzing empirical data from an inter-organizational one-stop government project in Sweden. Our experience from applying the framework is that it makes us focus on a set of interesting issues in our case and explains some of the challenges that our interviewees identified. By addressing these inter-organizational aspects we reached further understanding of the problems associated with this particular case, which can provide added value to the discussion of e-government challenges, barriers and problems in general.
\end{abstract}

\section{$1 \quad$ INTRODUCTION}

Many of today's e-government development efforts are made in the shape of public web portals. Public information and e-services are gathered at a website in order to provide easy access through one entrance to the agency. Such one-stop government solutions consist of integrated services that are made available from one single website, even if they are provided by different government agencies or private businesses (Wimmer \& Tambouris, 2002). This definition clearly states that one-stop government implies several interacting agencies in order to provide integrated services. Agency interaction is often recognized as interoperability between agencies (Millard et al., 2004). Interoperability comprises the ability of IT systems and business processes supported by these systems to exchange data in order to enable information and knowledge sharing between organizations (Tambouris et al., 2007). Operability exists on several levels; the technical level where linking of computers is handled, the semantic level where the meaning of concepts needs to be defined, and the organizational level where business goals and processes must be conformed between administrations (ibid.).

Despite this obvious necessity to interact and coordinate activities between agencies in order to realize integrated services, there are many studies showing that e-government initiatives suffer from poor coordination among agencies (e.g. Tranmüller \& Wimmer, 2003; Punia \& Saxena, 2004). There is an evident trend that agencies tend to act too independently, because the initiatives tend to be poorly coordinated (Irani, Love \& Montazemi, 2007). Dawes and Pardo (2002) also address, from an inter-organizational perspective, the existence of multiple, and partially conflicting, goals in the public sector. This behavior, thus, challenges reaching overall one-stop government objectives.

We use the concept of challenge to analyze and discuss the two-sided coin of one-stop government achieved by developing an inter-organizational web portal and e-services. There are, on one side, goals to fulfill by the web portal; such as easy and fast access to information and e-services, invisible organizational borders, and less need to understand which agency to contact in a certain matter. On the other side, there are problems with such web portals as well; not at least related to inter-organizational relationships and responsibility division between agencies. Challenge as a concept is used here to capture problems (cf. the definition by Merriam-Webster's Dictionary, 2007: “to arouse or stimulate especially by presenting with difficulties") and identify ways to fulfill the goals.

If we leave public administration for a moment and study the field of business interaction instead, we find many approaches focusing on interaction between organizations. A well-cited approach is the industrial/business network approach (e.g. Håkansson, 1982; Axelsson \& Easton, 1992; Håkansson \& Snehota, 1995) within the marketing area. This approach has been developed over the last thirty years and focuses on business interaction 
and relationships as important aspects to understand when explaining what happens in and between companies over time (Ford \& Håkansson, 2006). The fact that organizations depend on each other when doing business has been accepted for centuries. Inter-organizational aspects have been focused in organization theory, where interaction in dyads and networks are vital objects for research (cf. Håkansson \& Snehota, 2006).

In this paper we are therefore developing a conceptual framework consisting of inter-organizational concepts from the industrial/business network approach, which we apply on empirical findings from an e-government project. We do this in order to identify, describe and better understand inter-organizational challenges of one-stop government development. These concepts bear meaning and consist of knowledge derived in a specific context. They direct our focus into certain issues and help us see what otherwise might have been hidden. We apply the conceptual framework on our case in order to place inter-organizational challenges in the foreground.

The purpose of this paper is, thus, to develop a conceptual framework and explore how the theoretical concepts that characterize an inter-organizational relationship and its dimensions can help us focus certain aspects of onestop government development. The paper does not claim that the industrial/business network approach is possible to transfer as it is in its original setting into the e-government research field. Instead, we are inspired by the theory and, thus we use some concepts from the industrial arena in the e-government context. The main reason for doing this is to put an increased focus on the inter-organizational challenges which e-government suffers from according to several previous studies reported shortly above and in more detail in the following section.

After this introduction, the paper is organized in the following way; in the second section we discuss national aspects of one-stop government. Then we review previous e-government studies in order to investigate what interorganizational challenges that are reported in relation to one-stop government e-service development. We also discuss the notion of inter-organizational interaction and develop the conceptual framework in this section. The research design is reported in the third section, followed by an introduction to the empirical case in the fourth section. The empirical findings from interviews concerning one-stop e-government challenges are related to the conceptual framework in the fifth section. The outcome of this conceptual analysis is a number of identified interorganizational challenges. The paper is concluded in the sixth section, where we also make some statements about the need for further research efforts in this area.

\section{INTER-ORGANIZATIONAL INTERACTION IN ONE-STOP GOVERNMENT}

In this section we discuss some national, context dependent, aspects influencing public e-service development in general and one-stop government in particular. We also review selected previous studies of challenges in one-stop government projects. Furthermore, this section contains a presentation of the industrial/business network approach. This approach is the theoretical ground for our conceptual framework, the theoretical lens, through which we analyze the findings from our interviews.

\section{National Aspects of One-Stop Government}

First we need to base this discussion on the fact that national governments are structured differently (e.g. OECD, 2002). We have studied several Swedish national government agencies cooperating to implement a one-stop government e-service for issuing provisional driving licenses. Different ways of organizing the government structure will result in different issues to deal with in order to realize one-stop government. The Swedish model of public administration with semi-autonomous agencies has several effects that need to be taken into account when discussing challenges in e-government development, which differ from other countries. The Swedish model of public administration is in an international context unique, in being almost completely organized into agencies and, thus, having very small ministries. This might be a reason for an underdeveloped culture of cooperation between agencies, in the same way as Kubicek and Hagen (2000) distinguish in Finland.

According to OECD (2002), the Swedish model makes agencies more visible for citizens and, thus, less effort has to be put on hiding the government superstructure in order to help citizens navigate to the right agency. The high number of agencies and the fact that administration is more visible help compensate, to some extent, for the small number of one-stop government services in Sweden so far (ibid.).

One-stop government efforts made to solve the overall need for hiding the underlying government structure have been treated in various ways in different countries. To illustrate the differences, Sweden and Canada are good 
examples. The Canadian government has for a long period of time been developing a one-stop web portal solution in order to hide as much of the underlying structure from the citizens as possible (d'Auray, 2004). The aim in Canada is to provide all services in one place. On the other hand, Sweden has put little effort in this direction. Onestop government in Sweden is defined rather differently and less ambitiously as "one case, one contact" (Statskontoret, 2000). In contrast to the Canadian ambition Swedish government does not focus as strongly on a "one-stop shop", but rather on integration of agencies within a case process. The less ambitious meaning of onestop government in Sweden puts the main responsibility of one-stop government on the agencies. So far, weak guidance, directives, and financing come from central government. In the Swedish model decisions about prioritization and development are mainly made by the agencies. The Swedish National Audit Office (Riksrevisionen) has stated that central government did too little too late in order to promote the evolution of egovernment (Riksrevisionen, 2004).

\section{Inter-organizational Challenges in One-Stop Government}

Tranmüller and Wimmer (2003) characterize fragmentation and isolated development as a main problem that hinders successful e-government in many situations. They highlight the neglect of inter-agency cooperation as a reason for e-government not yet having exploited the enormous potential of, for example, one-stop government (ibid.). Punia and Saxena (2004) state that government services are performed by multiple agencies without any collaboration between them. Each agency handles its own part of the process without integrating with other associated agencies. Before changing this situation it is difficult (or even impossible) to succeed in any one-stop government effort (ibid.). Research on one-stop government e-services (e.g. Gouscos et al., 2003; Wimmer, 2001) and studies that relate to the reconstruction of inter-organizational case processes from the client point of view (e.g. Andersen, 2004) show other examples of the importance of agency interaction and cooperation. Kubicek and Hagen (2000) identify the lack of organizational cooperation as an important barrier that needs to be overcome in order to succeed in e-government efforts. Many e-government studies focus on central agencies, but Flak et al. (2005) have studied local e-government in Norway and they state that little is known about cooperation in egovernment on the local municipality level as well.

These and other findings make us claim that there is a significant need to view one-stop government from an interorganizational perspective. Obviously, agency interaction and cooperation should be an important object of analysis in e-government research. When e-government efforts increase in central or local agencies, the interorganizational interaction becomes an even more critical issue to focus on. There exist inter-organizational relationships and interaction both between organizations at the same level in the society hierarchy, which has shared responsibilities in a certain process, and between organizations at different geographical and hierarchical levels. Such vertical and horizontal relationships are not created by or through e-services or web portals, but the contexts that they are anchored in, and the way agencies chose to organize around their e-government and one-stop government efforts, challenge existing inter-organizational relationships and interaction.

The importance of one-stop government related issues and challenges are especially true in a decentralized government structure as Sweden's (OECD, 2002). Several national studies (Statskontoret, 2005a; Statskontoret, 2005b) conducted in Sweden address cooperation between agencies as the major future obstacle for improving the public sector performance in terms of e-government progress and development of one-stop government solutions. In a report from the Swedish agency for public management, (Statskontoret, 2005a), the differentiation and specialization incorporated in the division of the public sector into a large number of semi-autonomous agencies, is pointed out as a crucial issue to be managed now and in the near future.

Agencies with poor coordination and insufficient communication with other agencies, for example, will not solve these problems automatically by implementing public inter-organizational e-services or a web portal. Since interorganizational issues have been a research interest in organization theory and partially in the industrial marketing/purchasing area for decades, we argue that knowledge from this field should be transferred to the public context in order to explore what lessons public agencies could learn from industry in this matter.

Public e-services and e-government evolution are described in several stage models that have been presented by the research community, e.g. Layne and Lee (2001), Hiller and Belanger (2001) as well as by different organizational bodies such as the UN (2003). These models distinguish e-services on a basic level (published static information) from more complex services that need several agencies to cooperate in order to realize a transaction service or one-stop government service. Irrespective of the fact that these models have received some criticism (cf. 
Andersen, 2004; Goldkuhl \& Persson, 2006), they define cooperation between agencies in order to provide onestop government as the most challenging task on the scale from static information to interactive services.

Kubicek and Hagen (2000) have identified six key areas of barriers to be overcome in order to reach fewer delays, failures, and obstacles in one-stop government development. Their first key area is summarized as lack of organizational cooperation. Reasons for this situation are that every e-government project affects power structures and balances. Many agencies are afraid of losing their power of human, legal and financial resources and, thus, they hesitate to cooperative over organizational borders (ibid.).

This can be related to an observation from the Swedish context that the public e-service growth has been rather fast when providing e-services without any need for cooperation between agencies. The Swedish Road Administration, for example, has developed several e-services within the agency but only one in cooperation with other agencies. The same is valid for transactional e-services as, e.g., tax declaration and application for parental leave in Sweden. Until today, there are many e-services developed without any need for cooperation between agencies. E-services built on cooperation between agencies are so far much more rare. Since many sources (e.g. Tranmüller \& Wimmer, 2003) predict successful agency interaction to be a crucial issue for e-government to fulfill its promises, studies that increase our knowledge on inter-organizational challenges in one-stop government are necessary.

\section{Inter-Organizational Interaction - Developing a Conceptual Framework}

The industrial/business network approach, also named the Uppsala School (e.g. Axelsson \& Easton, 1992; Håkansson, 1982; Håkansson \& Snehota, 1995; Håkansson \& Snehota, 2006; Ford \& Håkansson, 2006), is a mature line of thinking that supports the understanding of interaction in business networks. Our thesis in this paper is that concepts from the industrial/business network approach can also help us to understand challenges in agency interaction in a one-stop government setting. Interaction is an aspect of reciprocal action or interplay; it is not the case of just one organization acting and the other organization reacting (ibid.). This is an important standpoint in the network approach, which is applicable in the public context as well.

If we take a closer look at the interaction between organizations we find several characteristics of relationships; (1) continuity (2); complexity; (3) symmetry; and (4) informality as structural characteristics of a relationship (Håkansson \& Snehota, 1995).

1. Continuity refers to the relative stability that tends to characterize supplier and customer relationships.

2. The complexity in a relationship can among other things comprise the number, type and contact channels for individuals from each organization who are involved in an inter-organizational relation. Also, contacts can vary at different levels in and between organizations.

3. It is typical for industrial relations that customers and suppliers are symmetrical in terms of resources and initiatives on each side. In those cases where asymmetry does occur, the customer tends to be bigger than the supplier is.

4. The relationships often demonstrate a low level of formality. Even though contracts exist, they are seldom referred to. Instead, contracts are often pointed out as being an ineffective way of dealing with uncertainty, conflict or crises in relationships which are going to survive for some time (Håkansson \& Snehota, 1995).

Another important aspect to study, when looking at interaction between organizations, is different dimensions of relations. In the industrial/business network approach, such dimensions are labeled as links, bonds, and ties. The various links, bonds and ties between organizations in an organizational network are important to consider when studying relationships (see e.g. Håkansson \& Snehota, 1995; Axelsson \& Easton, 1992).

The link concept refers to the connections that exist in the activities between organizations, so-called activity links. An activity is defined as: "a sequence of acts directed towards a purpose" (Håkansson \& Snehota, 1995, p. 52). Activities can be of various types, for example technical, administrative or commercial. The links between activities reflect the need for co-ordination which affects how and when various activities are carried out. Matching one actor's resources with others' is an example of an aim of purchasing and marketing functions within an organization. This, in turn, has consequences for both the costs of performing activities and their effectiveness (Håkansson \& Snehota, 1995). The links between activities make up a certain structure within the organization at the same time as it also creates certain patterns in the network. 
Bonds between actors in a network can be of various types, for example technical, social, time-based, knowledgebased, administrative, economic or legal (Håkansson \& Snehota, 1995). Bonds arise in relationships as two related actors mutually acquire meaning in their reciprocal acts and interpretations (ibid., p. 197). Bonds can have various aims, for example to achieve co-ordination as a means of saving resources. Gaining access to suitable cooperators and maintaining a certain position in the network are other examples of the importance of handling bonds. "Actors act and develop bonds; at the same time they are a product of their bonds” (ibid., p. 201).

A relationship between two organizations affects the way in which the organizations use their personnel, equipment, know-how, and financial resources, just to mention a few resources. A relationship between two organizations can comprise pooled resources of these kinds, so-called resource ties. The relationships between organizations are not just a way of assuring access to resources, they are also a way of getting various types of resources to meet, confront and combine (Håkansson \& Snehota, 1995), as well as to develop, create or refine resources.

We use this review of theoretical concepts that characterize an inter-organizational relationship and its dimensions when developing a conceptual framework, which is illustrated in table 1 and table 2. The conceptual framework consists of short examples of how the concepts can be translated to or interpreted in an e-government context. There is no explicit relation between the concepts of characteristics and dimensions. The set of concepts represents two complementary perspectives to understand and analyze an inter-organizational relationship.

Table 1. Conceptual framework of inter-organizational agency relationship characteristics

\begin{tabular}{l|l}
$\begin{array}{l}\text { Overall } \\
\text { relationships } \\
\text { characteristics }\end{array}$ & $\begin{array}{l}\text { Continuity: the relative stability that characterize a relation } \\
\text { between agencies, can e.g. be regulated by directives from the } \\
\text { government } \\
\text { Complexity: e.g. the number, type and contact patterns } \\
\text { between officials from different agencies involved in the relation }\end{array}$ \\
$\begin{array}{l}\text { Symmetry: in terms of balance in the amount of available } \\
\text { agency resources and capabilities in reciprocal relations with } \\
\text { e.g. initiatives, roles, responsibilities and missions } \\
\text { Level of formality: the whole range from high to low formality; } \\
\text { structural features of the agency relationship, e.g. in terms of } \\
\text { formal contracts to informal bonding such as past experience in } \\
\text { interaction, trust and confidence }\end{array}$
\end{tabular}

Table 2. Conceptual framework of inter-organizational agency relationship dimensions

\begin{tabular}{|c|c|c|}
\hline \multirow[t]{3}{*}{ Dimensions } & Links & $\begin{array}{l}\text { Technical: when agencies technically adjust their } \\
\text { activities to each other, e.g. through IT systems } \\
\text { Administrative: process related dimensions of a } \\
\text { relationship, e.g. concerning delivery frequencies, } \\
\text { communication patterns etc. } \\
\text { Activity: activities in interaction processes } \\
\text { Commercial: e.g. joint activities between agencies } \\
\text { that aims at lowering purchase costs; public-private } \\
\text { partnerships in order to generate ROI regarding e.g. } \\
\text { road construction etc. }\end{array}$ \\
\hline & Bonds & $\begin{array}{l}\text { Actor: bonds between e.g. officials that mutually } \\
\text { acquire meaning in their reciprocal acts and } \\
\text { interpretations in a relationship } \\
\text { Economic: economic prerequisites that the parties } \\
\text { create and influence regarding each others' activities } \\
\text { Legal: agreements that frame action and actions } \\
\text { alternatives regulated by the agencies themselves or } \\
\text { the government }\end{array}$ \\
\hline & Ties & $\begin{array}{l}\text { Resources: connected (pooled) resources between } \\
\text { two agencies that can be e.g. created, developed or } \\
\text { refined during interaction and an ongoing } \\
\text { relationship. Resources can be tangible or intangible. }\end{array}$ \\
\hline
\end{tabular}

We can identify several motives for applying this conceptual framework when analyzing our e-government case. First of all, the Swedish model for public administration implies that cooperation between agencies in Sweden relies on similar foundations as cooperation between private organizations. There is a large amount of semi- 
autonomous agencies that have to find ways to cooperate and coordinate their joint development projects. It is possible to view the Swedish government as a combine (cf. a group of companies), consisting of cooperating agencies (compare to independent; but cooperating companies). Thus, inter-organizational relationships between these agencies do have characteristics in common with business relationships in other organizational networks. Another reason for choosing the industrial/business network approach is that cooperation in the public sector sometimes involves financial exchange which makes the cooperation in this aspect similar to a business network.

There are of course other approaches on inter-organizational interaction that could have been chosen instead of the industrial/business approach. Ahlström (2000), for example, presents another model of business interaction and gives an overview of several other approaches. We recognize the industrial/business network approach as one of the most mature and developed approaches, though, and have chosen to use concepts from this approach as we find them well-grounded in empirical studies and in theory, relevant to our case, as well as conceptually stringent.

\section{RESEARCH DESIGN}

This paper reports on an interview study conducted during the fall 2005. Interviews were performed within the development project of an inter-organizational e-service and a one-stop government web portal concerning driving licenses. We have interviewed six persons who have the following roles in the interacting agencies; IT strategist, project leader, system manager, internal investigator, case handling officer, and IT development manager. The interviewees have been selected in order to reach a broad view of apprehensions regarding the studied e-service development project.

We have asked rather open questions in the interviews; for example: How do you understand the notion of eservice? What opportunities and threats do you apprehend regarding the e-service and web portal development? What kind of cooperation and coordination do you regard as necessary for this development project? The interviews had a semi-structured and semi-standardized design and were recorded. The basic approach when interviewing can be classified as a "general interview guide approach" (Patton, 1980, p. $198 \mathrm{ff}$.). A set of questions and issues where prepared as a guide for every interview - as interviewers we then were free to build an appropriate conversation interacting with each interviewee. Topics were allowed to emerge during the interviews (cf. Patton, 1980). The empirical data has been analyzed in a qualitative, interpretive way (Walsham, 1995), but not "purely" inductive. The conceptual framework derived from the industrial/business network approach (e.g. Håkansson, 1982; Axelsson \& Easton, 1992; Håkansson \& Snehota, 1995) has been used as a theoretical lens when analyzing empirical data, which means that the data analysis was conducted with a deductive and theorydriven approach. However this approach was not used during the generation of empirical data in the interview phase. That phase in the research process was more interpretative and explorative not using pre-defined categories and theoretical constructs.

\section{EMPIRICAL CONTEXT}

The interviews were, as mentioned in the section above, conducted within a research project concerning e-service development in the public sector in Sweden. The project is the case that is studied in this paper. The aim of the project has been to develop one-stop government e-services for driving license matters as well as a web portal where these e-services and information about the driving license process are easily accessible. The purpose of the project has been two-fold; (1) the project aims at facilitating citizens' authority contacts in driving license matters and (2) the project also aims at making the internal processes at the agencies more efficient. An important aim has been that the project should result in a service-oriented and inter-organizational one-stop government, in order to decrease unclear responsibility division between authorities. Three Swedish agencies have been involved in the project; Sweden's County Administrations (SCoA) which organizes the 21 county administrative boards of Sweden, the County Administrative Board of Stockholm and the Swedish Road Administration (SRoA).

The background to the project is that everyone in Sweden who wants to get a driving license, first has to apply for a provisional driving license to start taking driving lessons. The citizen applies for this provisional driving license from the county administrative board in the region where he or she lives (see figure 1 below). 


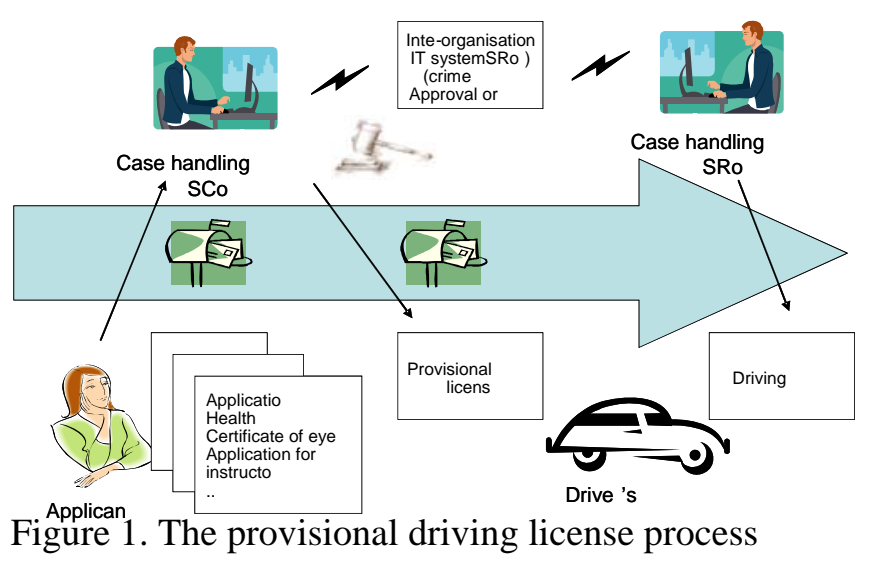

The provisional driving license is approved if the applicant is judged to be able to drive a vehicle in a safe way, thus, the permit is an important aspect of traffic security. The main aim of this regulation is, therefore, to find those who are not suitable to receive a permit. The permit application was, prior to the e-government project, a paper form that was filled in, signed and sent by mail to the agency. The application has to be complemented with a health declaration, a certificate of good eyesight from an optician, and maybe also an application that a parent is allowed to serve as a private instructor.

These documents are received and reviewed by a case handling officer at the agency, who decides whether the application is complete or not, and if there is any medical information that must be further examined. The case handling officer also checks if the applicant has been sentenced for any crime (such as being drunk in public places, drug possession, or any traffic misdemeanor). This information is registered in a special database operated by the police force which the case handling officer has access to through SRoA's IT system (the Road Traffic Register). When the provisional driving license has been granted, the county administrative board reports this to SRoA through their inter-organizational IT system. When the applicant has completed the driving test and the theoretical test successfully he or she finally receives the driving license from SRoA.

The process, described above, indicates that the administration of driving license issues is a true interorganizational task that involves several Swedish agencies. In 2004, Sweden's 21 county administrative boards together handled over 210.000 applications for provisional driving licenses. In as many as 80 percent of these cases, the decision was very easy to make - the permit was approved without any further examination. These are called "green cases" by the agency. Handling these green cases is an uncomplicated task, but since there are so many of these cases the review process is nevertheless time-consuming. This is the background to the present research project. By developing an e-service that makes a digital case handling process possible in all green cases, resources are saved at the agency. These resources will instead be used for administration of more complex cases.

There are other positive effects that the e-service generate; such as a higher degree of complete applications since the e-service checks for missed information before the application is submitted to the agency. The 21 agencies are also able to handle these issues in a standardized way and, thus, avoid any regional differences in judgment. Another important outcome of this e-service is that the applicants do not have to know which agency to contact in different phases of the process, as was the case before the e-service. Instead, the e-service will be an example of a one-stop government solution (Kubiceck \& Hagen, 2000), where borders between agencies are invisible for the applicants.

\section{EXPLORING CHALLENGES IN A ONE-STOP GOVERNMENT CASE}

In this section the inter-organizational relationship between SCoA, SRoA, and the County Administrative Board of Stockholm will be analyzed by using the conceptual framework of inter-organizational relationship characteristics and dimensions from the industrial/business network approach (summarized in table 1 and table 2), introduced in section two above. 
Continuity: the relationship between SCoA and SRoA is rather stable and mature. The present division of labor between the two parties in the driving license process was established in the mid 1990ies. The division of labor is regulated by the Swedish government. There are no present signals that the division of labor will change in the foreseeable future.

Complexity: there is a significant number of actors involved in the relation. SCoA is an umbrella organization which consists of 21 county administrative boards representing different regions in Sweden (e.g. Stockholm). This complexity is expressed as severe in the interview with the project leader, with reference to the development project:

The ambition to work all 21 county administrative boards together in this project implies a severe complexity, there are so many that need to be in the boat. (Project leader, SCoA, Sept 2005)

SRoA is, in this study, mainly represented by the Road and Traffic Register Unit (handling e.g. vehicle registration, provisional driving licenses and full driving licenses). There are also a significant number of contacts between SCoA and SRoA in order to handle over 210.000 applications for provisional driving licenses each year. Types of contacts represented are face-to-face (in different joint action groups on operative and strategic level), informal daily phone or email contacts and established email lists for knowledge sharing. Another example of complexity is the difference in case handling procedures and interpretations of the legal framework between the SCoA's in different regions. The IT strategist states the importance of dealing with this matter in this way:

We cannot have services that differ between the county administrative boards in different regions, with respect to equality before the law, this must be improved. [...] That can only be achieved with increased cooperation. (IT strategist, SCoA, Sept 2005)

Symmetry: SRoA has an overall responsibility for national road traffic issues sanctioned by the Swedish government. With reference to this symmetry aspect the IT strategist expresses the subordinate position of SCoA in relation to other agencies in general as:

A unique characteristic in our relations to other agencies is that we often have a subordinate position or provide services to central government agencies. (IT strategist, SCoA, Sept 2005)

SCoA has at the same time a regional responsibility to handle certain issues in a particular part of the country and specific activities in the provisional driving license handling process (e.g. handling the review process). SCoA has also got a specific mission from the government to develop the e-service studied here.

Level of formality: there is a high level of formality concerning the division of labor between SCoA and SRoA regulated by the Swedish government. This certainly has an influence on the relationship. The division of labor is discussed, and criticized by actors in both organizations. In the interview a case handling officer at SCoA states that:

There is a rivalry between SRoA and SCoA, some people express that our case handling in driving license matters should be organized within SRoA instead. (Case handling officer, SCoA, 2005-10-03)

Statements similar to this are also identified within interviews at SRoA. The joint e-service development project that we study, on the other hand, has a low level of formality. The low level of formality in the e-service development project, clashes with SRoA's way of organizing IT development projects. SRoA has a tradition of structuring large scale development projects (e.g. constructing bridges, roads etc.) and uses distinct project management skills and approaches in recurrent projects. SCoA, and the County Administrative Board of Stockholm, have a more ad-hoc way and culture of handling projects, often based on the engagement of real enthusiasts (project champions) not allocating direct resources (e.g. project leader time) etc.

\section{$5.2 \quad$ Relationships Dimensions}

\subsubsection{Links}

There is one significant technical link in the present relation. SRoA supplies the IT system (the Road Traffic Register) that the 21 county administrative boards use as a significant tool in the daily process of handling applications for provisional driving licenses. The e-service implies a change in this technical link; SRoA does not 
supply access to the IT system anymore but only strings of data requested from the 21 county administrative boards.

Administrative and activity links: the total administrative process for handling provisional driving licenses is rather disintegrated. SRoA provides certain prerequisites (e.g. the IT system, content demands on the application forms etc.), and has the overall responsibility for the road traffic sector. Each county administrative board, then, handles main activities in the review process, and SRoA handles the payment processes and issues the provisional driving license (and later on the full driving license). Consequently, there are a number of sequential interdependencies between activities in the process. The disintegrated process also makes the pattern of communication and cooperation complicated, as we discussed above. One aspect of activity links in the relation is also the level of adaptation to the other party. SCoA has to adapt to the IT system supplied by SRoA; but has some free scope for expressing demands on data from the IT system and the use of the IT system. We have also identified that SRoA's IT division has started to raise the requirement for SCoA to make certain design decisions in a certain time, when developing their e-services. This is done in order to get SCoA to adapt to SRoA's IT application requirements and IT development project model.

\subsubsection{Bonds}

Actor bonds: some activity links are established and organized in order to strengthen bonds between actors from the different organizations. There are mainly two joint action groups; one on the operative level and one on the strategic level. The operative joint action group deals with activities in the license handling process and the use of the IT system. The strategic joint action group deals with decision making and plans at a strategic level, concerning the present process and the IT system support. However, the bonds between the two joint actions groups are weak. Different actors are represented in the two groups and the communication between them is weak. Bonds between actors are also influenced by the history of the relation between the organizations. As mentioned above the division of labor is criticized and discussed. It is possible to identify different opinions about the division of labor and activities between the parties, partially related to the historical division, but mainly concerning how to organize future processes and e-services. This situation sometimes makes the social bonds between the actors rather tensed when interacting in the present development project.

Economic bonds: as mentioned briefly above the payment process when handling provisional driving licenses is disintegrated. SCoA performs the main part of the process related to handling applications, while SRoA supplies SCoA with data from the IT system, content of application forms, etc. and handles payments from the applicants. SRoA then compensates SCoA for the handling activities by transferring funds to the organization. The funds do, however, only compensate for handling the completed granted permits, not the handling of the more timeconsuming and more complicated "red cases", where a provisional driving license is denied. This latter type of cases remains uncompensated.

Legal bonds: as mentioned above SCoA has a specific mission from the Swedish government to develop eservices. That mission defines the bonds between SCoA and SRoA. SRoA has to do what is required in order to help SCoA to complete the effort to develop e-services. The fact that a public agency should provide what another agency needs within its area of expertise is also stated in the law that regulates the inter-organizational work of agencies. At the same time, SRoA has the overall responsibility for the national road traffic issues sanctioned by the government. This fact also influences the bonds between the parties and the symmetry (as stated above) in the relation.

\subsubsection{Ties}

Resource ties: the studied organizations pooled resources (personnel and know-how) in order to develop e-services in the joint development project, which has been managed by the County Administrative Board of Stockholm. Although various resources were pooled in the project, there are some asymmetry aspects in this joint effort. First of all, there were few persons in the project representing SRoA, even though the e-service development was depending on SRoA's participation. It would, for example, be impossible to operate the e-service without appropriate changes in SRoA's IT system. SRoA is, according to Swedish law, responsible for deciding the content of the application forms. This know-how was obviously an important resource in the project. Another asymmetry issue is that the project was initiated and managed by SCoA, who also had the specific mission from the government to develop the e-service. This resulted in deviating incentives between the agencies, which can be an explanation to the asymmetry in pooled resources as, for example, the project representation. 
The e-service development project is an example of a joint project between the two organizations. This project tied resources together, was based on actors bonds and developed actor bonds further. The project also aimed at developing technical (IT support) and administrative links (re-designed administrative processes) between the organizations further. Both parties were investing financial resources in this project, both in terms of time spent on project related development and money spent on consultants. Investing financial resources in an interorganizational project implies, however, a risk of disagreeing priorities regarding the amount of resources (e.g. time and money) between the agencies. The project was not the only reason for financial resource ties between the organizations. Another example of exchange of financial resources between the two organizations is when SRoA collects the payment from the license holder (see "links" above) and transfers this resource to the issuing county administrative board.

Knowledge was also invested in the joint project that ties the two parties together. SRoA has experiences of earlier e-service development projects that were useful for this project. Knowledge was also developed as a result of the joint project, both as more experienced individuals in the two organizations and as a resource tie between the agencies, i.e. knowledge about this particular inter-organizational process and experience of inter-organizational eservice development projects.

The empirical findings discussed above are summarized as inter-organizational e-government challenges in table 3 and table 4 below.

Table 3. Summary of inter-organizational e-government challenges - relationship characteristics

\begin{tabular}{|l|l|l|}
\hline $\begin{array}{l}\text { Overall } \\
\text { Relationship } \\
\text { Characteristics }\end{array}$ & Continuity & $\begin{array}{l}\text { Stable and mature relationship, which } \\
\text { seems to be less challenging than the } \\
\text { opposite }\end{array}$ \\
& Complexity & $\begin{array}{l}\text { Diverse conceptions about the components } \\
\text { of the complexity in the relationship (many } \\
\text { agency actors and many citizens' } \\
\text { applications) } \\
\text { Goal conflicts between several overarching } \\
\text { roles, responsibilities and missions } \\
\text { Siffering apprehensions about division of } \\
\text { labor and responsibility } \\
\text { Variation in project management } \\
\text { approaches/cultures }\end{array}$ \\
\hline Level of \\
formality
\end{tabular}

Table 4. Summary of inter-organizational e-government challenges - relationship dimensions 


\begin{tabular}{|c|c|c|}
\hline Links & $\begin{array}{l}\text { Technical } \\
\text { Administrative } \\
\text { Activity } \\
\text { Commercial }\end{array}$ & $\begin{array}{l}\text { Inter-organizational IT system; ownership, } \\
\text { dependencies } \\
\text { Disintegrated process with many contacts } \\
\text { and deliveries between agencies } \\
\text { Complicated patterns of communication and } \\
\text { cooperation } \\
\text { Sequential interdependencies between } \\
\text { activities in the two agencies } \\
\text { [Not applicable in this case] }\end{array}$ \\
\hline Bonds & $\begin{array}{l}\text { Actor } \\
\text { Economic } \\
\text { Legal }\end{array}$ & $\begin{array}{l}\text { Gap between participants in working groups } \\
\text { on different hierarchical levels within and } \\
\text { between agencies } \\
\text { History influences opinions of the present } \\
\text { and future division of working task between } \\
\text { agencies } \\
\text { Complex principles for compensation; some } \\
\text { tasks are resource demanding but } \\
\text { uncompensated } \\
\text { The agencies have several external } \\
\text { assignments and both superior and inferior } \\
\text { roles towards each other }\end{array}$ \\
\hline Ties & Resource & $\begin{array}{l}\text { Asymmetry in incentives for the joint project } \\
\text { influences the amount of resources spent on } \\
\text { the project } \\
\text { Knowledge is both a resource used in the } \\
\text { project and an outcome from the project; i.e. } \\
\text { competence development on individual and } \\
\text { organizational level }\end{array}$ \\
\hline
\end{tabular}

\section{CONCLUSIONS AND FURTHER RESEARCH}

As we stated in the introduction of the paper, fragmentation and isolated development are main problems that hinder successful e-government in many situations (Tranmüller \& Wimmer, 2003). The lack of inter-agency cooperation is one reason for e-government not yet having reached its full potential of for example one-stop government (ibid.). This paper therefore has an explicit inter-organizational perspective on challenges in one-stop government. In order to capture the inter-organizational perspective we have presented a conceptual framework derived from the industrial/business network approach (e.g. Håkansson, 1982; Axelsson \& Easton, 1992; Håkansson \& Snehota) that characterizes an inter-organizational relationship, its characteristics and dimensions. The conceptual framework helps us focus certain aspects of one-stop government development.

We had, through our previous research, distinguished similarities between inter-organizational development projects in the public sector and the commercial sector, that made us focus on the possibility of borrowing theoretical concepts from the industrial/business network research. With this theoretical lens we have analyzed empirical data (mainly generated by interviews) from a one-stop government e-service development project.

So are the inter-organizational concepts from the industrial/business network approach useful when trying to identify, describe and better understand inter-organizational challenges of one-stop government development? We argue that the answer to that question is "yes". We have used the conceptual framework for analyzing findings from an e-government project. The illustrations (e.g. in table 3 and table 4) have been fruitful in order to focus on inter-organizational challenges in one-stop government. The analysis has been more focused and more structured than would have been the case if we had been analyzing the empirical material without this conceptual framework, in a more inductive way. In the spirit of the industrial/business network approach we have also been focusing the present situation and been able to give a rather detailed and fine-grained picture of the problems and challenges in this context. This is a difference compared to many other e-government studies that normally have been focused on future possibilities and solutions.

The inter-organizational challenges in one-stop government, which we identified from analyzing the studied onestop government project (which is poorly coordinated in several aspects), also corroborate the previous findings in the literature from, e.g., Wimmer and Tambouris (2002); Tranmüller and Wimmer (2003); Punia and Saxena (2004). 
If we take a look at our findings in a European context, the findings can be related to the European study of the need to re-organize back-office processes in order to provide e-services of high quality to citizens (Millard et al., 2004). In this extensive study of 29 in-depth cases, structural changes between agency processes are pointed out as a way to improve inter-organizational coordination and integration. Millard et al. (ibid., p. 186) show that interoperability is easiest achieved between agencies which have a tradition of inter-organizational cooperation.

In another study on European basis (Tambouris et al., 2007, p. 45), seven key factors for reaching organizational operability have been identified. Compared to our proposed framework, these key factors are more concrete and normative in their formulations. On the other hand, the key factors concern issues that are handled in our framework. For example, the factor "Clear link between cross-organisational processes/services and the business strategies of the broader agencies" (ibid.) concerns the "link dimension” in our framework.

Bekkers (2005) reports on a Dutch study of back-office integration in e-government, which identifies the importance of mutual recognition of core values and interdependency between values (win-win situations). The study indicates that interdependency between agencies can only be successful if involved actors focus on the nature of the problem to be solved. Different rationalities compete and each rationality stresses specific core values, which might be conflicting. Bekkers mentions the political, legal, organizational, economical, and technological rationality (ibid.). Our framework can be used for identifying some of these core values and competing rationalities in an inter-organizational relationship; e.g. using technical links and economic and legal bonds.

Concerning the concept of interoperability, our study has focused on and explicitly dealt with issues related to the organizational level of interoperability. In an overall perspective, it is of course also important to consider challenges at the technical and semantic levels of interoperability in order to handle one-stop government from an inter-organizational perspective.

In this paper we have used empirical data consisting of, e.g., statements as our point of departure. These statements represent different actors' views of the challenges in the studied one-stop government project. The statements have been systematically arranged and discussed as being related to different relationship dimensions from the industrial/business network approach, as stated above. This way of action has provided us with important insights in this particular development project, of course, but the result can also be used as a tool for analysis and evaluation of other future or on-going one-stop government projects. The conceptual framework of interorganizational agency relationship characteristics and dimensions (table 1 and table 2) is, thus, a result in itself. The proposed framework can be used in order to analyze and evaluate one-stop government development efforts in, e.g., projects.

It is always important to discuss the possibilities (strengths and weaknesses) when transferring results from egovernment research between nations with different government structures. As we regard the results from this study, the use of the framework is not limited to decentralized government structures as Sweden's. The framework used in this paper has not been inductively developed based on our case. Instead, it was derived from theory and then applied to a Swedish case of one-stop government. The framework in itself should, thus, be possible to use in different governmental contexts and for different e-services than the one studied, even though the outcome from applying the framework of course might differ.

By applying the industrial/business network approach on this current development project we also gained a deeper understanding of history, motives and incentives that bear impact on the challenges in this particular project. These aspects of history are important in order to understand one-stop government projects and to be able to deal with present challenges. Although commonly identified barriers of one-stop government are very important to address, we believe that this approach, focused on inter-organizational relations, helps us focus better on the interorganizational aspects of fragmented public agency superstructures. By addressing these inter-organizational categories we reached further understanding of the problems associated with this particular case. Experiences from this and coming applications of the conceptual framework can, as we see it, provide added value to the discussion of e-government barriers and key areas as discussed by, for example, Kubicek \& Hagen (2000), Wimmer \& Tambouris (2002).

Of course, there is a danger in transferring theories from one field (interaction in business and industrial markets) to another field (interaction between agencies in the public sector). This is obviously not always applicable, and the explanation force in a theory does not necessarily have to be the same when used in another field. Nevertheless, we argue that the relationship characteristics that we have borrowed from the industrial/business 
network approach have been useful in this case when analyzing agencies from an inter-organizational perspective. The concepts related to relationship characteristics and dimensions helped us to focus on certain interesting issues in our empirical material and seem to be able to explain some of the challenges that our interviewees identified.

By focusing on relationship characteristics and dimensions using an inter-organizational perspective, we have consciously been neglecting the perspectives of citizens and civil society in favor of a government perspective. This does not imply that a government perspective is enough in order to understand the complexity when identifying and handling challenges in one-stop government. Further studies are needed where actors outside the inter-organizational relationship are studied as well; for example the government that is responsible the overall regulation of the agency structure, division of labor, etc.

We also identify a need for studies of several e-service projects in order to get variation and more experiences of applying the relationship characteristics and dimensions on e-government research. Another subject for future studies is to expand the scope from analyzing a particular relation (a dyadic relationship) to studying a network of agencies in order to get the full benefit of important perspectives in the industrial/business network approach. Such studies can highlight, e.g., the interaction and coordination patterns and logic between agencies (c.f. Tranmüller \& Wimmer, 2004) from a network perspective.

\section{References}

Ahlström, M. (2000). Offset Management for Large Systems - A Multibusiness Marketing Activity. PhD dissertation, Department of Management and Economics, Linköping University.

Andersen, K.V. (2004). E-government and Public Sector Process Rebuilding (PPR): Dilettantes, Wheelbarrows and Diamonds. Kluwer, Boston.

d'Auray, M. (2004). The dual challenge of Integration and Inclusion: Canada's experience with Government Online. In The World of E-government, Haworth Political Press, New York.

Axelsson, B. and Easton, G. (Eds. 1992). Industrial Networks: A New View of Reality. Routledge, London.

Bekkers, V. (2005). The Governance of Back Office Integration in E-Government: Some Dutch Experiences. In: Wimmer, M.A., Tranmüller, R., Grönlund, Å. and Andersen, K.V. (Eds.) EGOV 2005, LNCS 3591, SpringerVerlag Berlin Heidelberg, pp. 12-25.

Dawes, S.S. and Pardo, T.A. (2002). Building collaborative digital government systems. In: McIver, W.J. and Elmagarmid, A.K. (Eds.) Advances in digital government. Technology, human factors, and policy, Kluwer Academic Publishers, Norwell, MA, pp. 259-273.

Flak, L.S., Olsen, D.H. and Wolcott, P. (2005). Local E-Government in Norway - Current Status and Emerging Issues. Scandinavian Journal of Information Systems, 17(2), pp. 41-84.

Ford, D. and Håkansson, H. (2006). The idea of business interaction. The IMP Journal, 1(1), pp. 4-27.

Goldkuhl, G. and Persson, A. (2006). From e-ladder to e-diamond - re-conceptualising models for public eservices. In Ljungberg J, Andersson M (eds., 2006) Proceedings of the 14th European Conference on Information Systems (ECIS2005), Göteborg, Sweden 12-14 June 2006.

Gouscos, D. Lambrou, M. Mentzas, G. Georgiadis, P. (2003). A Methodological Approach for Defining One-Stop e-Government Service Offerings. In Proceedings of Electronic Government, Second International Conference, pp. 173-176.

Hiller, J., Bélanger, F. (2001). Privacy strategies for electronic government. E-government series, Endowment for the business of Government, Pricewaterhouse Coopers, Arlington, VA.

Håkansson, H. (Ed. 1982). International Marketing and Purchasing of Industrial Goods - An Interaction Approach. IMP Project Group, John Wiley \& Sons, Chichester.

Håkansson, H. and Snehota, I. (Eds. 1995). Developing relationships in business networks. Thomson, London.

Håkansson, H. and Snehota, I. (2006). No business is an island: The network concept of business strategy. Scandinavian Journal of Management, 22 (2006), pp. 256-270.

Irani, Z., Love, P.E.D. and Montazemi, A. (2007). E-government: past, present and future. European Journal of Information Systems. 16, pp. 103-105.

Kubiceck, H. and Hagen, M. (2000). One Stop Government in Europe: An Overview. In Hagen, M., Kubicek, H. (Eds. 2000). One Stop Government in Europe. Results from 11 National Surveys. University of Bremen, Bremen 2000, pp. 1- 36.

Layne, K. and Lee, J. (2001). Developing Fully Functional E-government: A four-stage model. Government information quarterly, 18(2), pp. 122-136.

Merriam-Webster’s Collegiate Dictionary Online, http://search.eb.com/dictionary, Accessed June 14, 2007. 
Millard, J., Iversen, J.S., Kubicek, H., Westholm, H. and Cimander, R. (2004). Reorganisation of government back-offices for better electronic public services - European good practices. Vol. 1: Main report. European Commission, Brussels (2004)

OECD (2002). Distributed Public Governance: Agencies, authorities and other government bodies. OECD Publications, Paris.

Patton, M.Q. (1980). Qualitative Evaluation Methods, Sage Publications.

Punia, D.K. and Saxena, K.B.C. (2004). Managing Inter-organisatinal Workflows in eGovernment. In Janssen, M., Sol, H.G. and Wagenaar, R.W. (Eds. 2004) Proceedings of the $6^{\text {th }}$ International Conference on Electronic Commerce (ICEC), 24-26 October 2004, Delft, pp. 500-505.

Riksrevisionen, (2004). Vem styr den elektroniska förvaltningen?, [In Swedish] Who governs the electronic public administration? Riksrevisionen, Stockholm.

Statskontoret, (2000). The 24/7 Agency: Criteria for 24/7 Agencies in the Networked Public Administration, Report 2000:41 Statskontoret, Stockholm.

Statskontoret, (2005a). Sektorisering inom offentlig förvaltning, [In Swedish] Sectorization within public administration, Report 2005:3 Statskontoret, Stockholm.

Statskontoret, (2005b). Mot en modern och sammanhållen förvaltning: Dilemman och strategiska vägval i förvaltningspolitiken, [In Swedish] Towards a modern and coordinated public administration: Dilemmas and strategic turning points in public governance, Report 2005:124 Statskontoret, Stockholm.

Tambouris, E., Tarabanis, K., Peristeras, V. and Liotas, N. (2007). D2.7 Study on Interoperability at Local and Regional Level. Final Version - Version 2.0. European Commission.

Tranmüller, R. and Wimmer, M.A. (2003). E-Government at a Decisive Moment: Sketching a Roadmap to Excellence. In Tranmüller, R. (ed., 2003) EGOV 2003, LNCS 2739, Springer-Verlag Berlin Heidelberg, pp. 114.

UN, (2003). World public sector report: E-government at the crossroads. United Nations, New York.

Walsham, G. (1995). Interpretive case studies in IS research: nature and method. European Journal of Information Systems, 4, pp. 74-81.

Wimmer, M. (2001). European Development towards Online One-stop Government: The "eGOV” Project. In Proceedings of the International Conference on Electronic Commerce (ICEC2001), Vienna.

Wimmer, M. and Tambouris, E. (2002). Online One-stop Government: A working framework and requirements. In Proceedings of the IFIP World Computer Congress, 2002, Montreal. 